\title{
Description of the male of Psyllaephagus euphyllurae (Masi) (Hymenoptera, Encyrtidae), a parasitoid of the olive psylla, Euphyllura olivina (Costa) (Hemiptera, Liviidae), with notes on its reproductive traits and hyperparasitoids
}

\author{
S.V. Triapitsyn, ${ }^{1}$ J.M.L. Jones, ${ }^{1}$ C.H. Pickett, ${ }^{2}$ M.L. Buffington, ${ }^{3}$ P.F. Rugman-Jones, ${ }^{1}$ K.M. Daane ${ }^{4}$ \\ ${ }^{1}$ Department of Entomology, University of California, Riverside, CA; ${ }^{2}$ Biological Control Program, \\ Integrated Pest Control Branch, Plant Health and Pest Prevention Services, California Department \\ of Food and Agriculture, Sacramento, CA; ${ }^{3}$ Systematic Entomology Laboratory, USDA-ARS, c/o \\ National Museum of Natural History, Smithsonian Institution, Washington, DC; ${ }^{4}$ Department of \\ Environmental Science, Policy and Management, University of California, Berkeley, CA, USA
}

\begin{abstract}
A colony of the encyrtid wasp Psyllaephagus euphyllurae (Masi) (Hymenoptera, Encyrtidae) has been established in the quarantine laboratory at the University of California, Riverside, California, USA as part
\end{abstract}

Correspondence: Serguei V. Triapitsyn, Department of Entomology, University of California, Riverside, CA 92521, USA.

Tel.: +1.(951).827.7817 - Fax: +1.(951).827.3086.

E-mail: serguei@ucr.edu

Key words: Encyrtidae, Psyllaephagus euphyllurae, host association, Liviidae, olive psylla, Euphyllura olivina, classical biological control, taxonomy, Spain, Apocharips trapezoidea, Pachyneuron sp.

Acknowledgments: the first author thanks his father Prof. Vladimir A. Trjapitzin (Moscow, Russia) and Dr. André Panis (Montauroux, France) for providing valuable information on $P$. euphyllurae, Prof. Gennaro Viggiani (Portici, NA, Italy) for the loan of its type material, Mr. Vladimir V. Berezovskiy (Irvine, CA, USA) for mounting the voucher specimens, Dr. Roger A. Burks (University of California at Riverside, USA - UCR) for confirmation of the identification of Pachyneuron sp. and also for taking two digital images, and Mr. Ryan Perry (UCR) for taking a photograph of the lectotype of Encyrtus euphyllurae. The second author thanks Dr. Thomas A. Miller for supervision of the project at UCR and also Dr. Genet M. Tulgetske (UCR) for establishing a colony of the olive psylla in the quarantine. Authors also thank Drs. Juan Antonio Sánchez and Michelangelo La Spina (IMIDA, Murcia, Spain), Dr. Kim A. Hoelmer (USDA-ARS, Newark, DE, USA), and Ms. Marie Roche (USDA-ARS European Biological Control Laboratory, Montferrier-sur-Lez, Montpellier, France) for assistance with collecting.

Received for publication: 19 May 2014.

Revision received: 5 July 2014.

Accepted for publication: 9 July 2014.

(C) Copyright S.V. Triapitsyn et al., 2014

Licensee PAGEPress, Italy

Journal of Entomological and Acarological Research 2014; $46: 4092$ doi:10.4081/jear.2014.4092

This article is distributed under the terms of the Creative Commons Attribution Noncommercial License (by-nc 3.0) which permits any noncommercial use, distribution, and reproduction in any medium, provided the original author(s) and source are credited. of a classical biological control program against its invasive host, the olive psylla, Euphyllura olivina (Costa) (Hemiptera, Psylloidea, Liviidae), an important pest of olives in some parts of the world. The colony originators were reared from the same host found on abandoned, commercial olives in Catalonia, Spain; additional collections were made in Murcia. The parasitoid reproduces primarily by thelytoky; however, a few occasional males have been found in the field in Spain, but not in colonies reared under quarantine or laboratory conditions. Here, the female of $P$. euphyllurae is redescribed and its male is described and illustrated for the first time; the only previous mention of male $P$. euphyllurae was from Tunisia, reared from the same psyllid host but without any details on its morphology. A lectotype is designated for Encyrtus euphyllurae Masi. Information is given on the results of genetic matching between the two sexes of the parasitoid and also on the presence of the bacterial Wolbachia symbiont that apparently is affecting reproduction of this species, including its sex ratio in the field. Two species of hyperparasitoids have also emerged from the parasitized olive psylla nymphs from Catalonia: numerous specimens of Apocharips trapezoidea (Hartig) (Hymenoptera, Figitidae) and one specimen of a Pachyneuron sp. (Hymenoptera, Pteromalidae).

\section{Introduction}

The olive psylla, Euphyllura olivina (Costa) (Hemiptera, Psylloidea, Liviidae), was first reported in California, USA in 2007 infesting olive trees (Olea europaea L.) in San Diego and Orange counties. It has now spread to Riverside and Los Angeles counties and has been found on olive trees at one private residence in Monterey County (Pickett and Rung, unpublished data, 2010). We anticipate it spreading north into commercial production regions of central and northern California. This pest naturally occurs throughout the Mediterranean Basin, both coastally and inland, and exclusively attacks the flower blossoms and growing tissue of olive (Tzanakakis, 2006). The olive psylla is reproductively active during spring months when nymphal populations can cause significant reductions to the olive fruit set. Spring infestations have been reported reducing fruit yields by up to $60 \%$ in some parts of the Mediterranean Basin (Jardak et al., 1985; Tzanakakis, 2006). The only known primary parasitoid attacking this pest in the western Mediterranean Basin, Psyllaephagus euphyllurae (Masi) (Hymenoptera, Encyrtidae) (Mercet, 1921; Aversenq et al., 2005), has 
been collected as part of an importation effort to introduce into California host specific natural enemies to control olive psylla. Specimens were collected in May 2013 from both the provinces of Catalonia and Murcia, Spain, and colonies of this species have been established at the University of California, Riverside, California, USA (hereafter UCR) Quarantine Facility. Currently cultures of both this parasitoid and olive psylla are being maintained at this laboratory to conduct studies on the host specificity of $P$. euphyllurae, needed for a field release permit from the United States federal government. Our long-term goal will be to establish permanent populations of $P$. euphyllurae in southern California, before the olive psylla spreads farther north into the major commercial olive production areas.

Psyllaephagus euphyllurae is primarily a thelytokous endoparasitoid. Since the first collections made in 2009 , we learned that it is active during spring months; it stops reproducing in July and aestivates as a preadult (inside its host's mummy) until the following spring (Pickett, unpublished data, 2012-2014). As a result, culturing quantities of adults needed for host range testing is difficult or impossible. Adequate numbers were obtained by collecting large numbers of parasitized olive psylla nymphs during May 2013 in Spain on abandoned, commercial olives; these were then hand-carried to the UCR quarantine. Approximately 500 adults were produced for the host range testing studies conducted in 2013. From this large field collection, three males were discovered from the populations of $P$. euphyllurae in Spain. Although there is one published report on a male associated with this species in Tunisia (Ferrière, 1961), there are no published descriptions of the male. Herein we provide such a description using both traditional morphological features and molecular genetics.

\section{Materials and methods}

Parasitized nymphs of $E$. olivina were brought in May 2013 from Spain, under the appropriate federal permit, into the quarantine laboratory at UCR where the emerging parasitoids were then collected. The emerged females of the encyrtid wasp $P$. euphyllurae were exposed to the different instars of the olive psylla, a colony of which had been established earlier on small olive plants in UCR quarantine under the appropriate state permit. A colony of the parasitoid has been successfully established and maintained ever since; the continuing colony originators all came from the specimens collected in Catalonia.

All the original parasitoids that emerged in UCR quarantine in the course of this study were preserved in $95 \%$ ethanol as voucher specimens (both $P$. euphyllurae and the hyperparasitoids) and then labeled and deposited in the collection of the Entomology Research Museum, University of California at Riverside, California, USA (UCRC) except for some specimens of the hyperparasitoid Apocharips trapezoidea (Hartig) (Hymenoptera, Figitidae, Charipinae), as indicated in the Material examined section for this species, which are deposited in the National Museum of Natural History, Washington, District of Columbia, USA (USNM) along with the specimens of $A$. trapezoidea from France. Additional specimens of $P$. euphyllurae collected in France, Greece and Spain in 2009, determined by John S. Noyes (the Natural History Museum, London, England, UK), are deposited in the California State Collection of Arthropods, California Department of Food and Agriculture, Sacramento, California, USA (CSCA). The syntype specimens of $P$. euphyllurae were received on loan from Dipartimento di Entomologia e Zoologia Agraria Filippo Silvestri, Università degli Studi di Napoli Federico II, Portici, Napoli, Italy (DEZA). All other identifications were made by S.V. Triapitsyn except for that of A. trapezoidea which was made by M.L. Buffington. Selected specimens were critical point dried from ethanol and then point-mounted, of which one female and one male of $P$. euphyllurae were dissected and slide-mounted in
Canada balsam, examined under a Zeiss Axioskop 2 plus compound microscope using Nomarski differential interference contrast optics, and photographed using the Auto-Montage ${ }^{\circledR}$ system; the photographs were then retouched where necessary using Adobe Photoshop ${ }^{\circledR}$.

Terms used for morphological features are those of Gibson (1997). Abbreviations used are: $\mathrm{F}=$ antennal funicle segment; mps=multiporous plate sensillum or sensilla on the antennal flagellar segments (=longitudinal sensillum or sensilla or sensory ridge(s) of authors).

DNA extraction, sequencing and assessment of Wolbachia infection status. Two male (from the field) and eleven female (4 from the field, 7 from the laboratory) $P$. euphyllurae were killed in $95 \%$ ethanol and subjected to individual non-destructive DNA extraction using the EDNA HiSpEx Tissue Kit (Saturn Biotech, Perth, Australia) and the manufacturer's protocol for extraction from $1 \mathrm{~mm}^{3}$ of tissue. The same methods were also used to extract the DNA from a single female Pachyneuron sp. For post-extraction, each specimen carcass was retrieved, stored in $70 \%$ ethanol, and deposited in UCRC.

Molecular confirmation that males and females of $P$. euphyllurae indeed represented the same species was sought by sequencing the ribosomal internal transcribed spacer 2 (ITS2) gene of one male and two female specimens (denoted by an * in the Material examined section for $P$. euphyllurae below). The ITS2 was amplified via the polymerase chain reaction (PCR) using the primers 58SF (5'-GTGAACTGCAGGACACATGAAC-3'; Porter \& Collins, 1991) and ITS4 (5'-TCCTCCGCTTATTGATATGC-3'; White et al., 1990). Reactions were performed in $25 \mu \mathrm{L}$ volumes containing, 1x ThermoPol Buffer (New England BioLabs, Ipswich, MA, USA), $200 \mu \mathrm{M}$ each dNTP, $200 \mathrm{nM}$ each primer, 1 $\mathrm{U}$ Taq DNA Polymerase (NEB), an additional $1 \mathrm{mM} \mathrm{MgCl}_{2}$, and $2.0 \mu \mathrm{L}$ DNA. The PCR was performed on a Mastercycler ${ }^{\circledR}$ gradient thermocycler (Eppendorf AG, Hauppauge, NY, USA) programmed for an initial $95^{\circ} \mathrm{C}$ for $3 \mathrm{~min}$; followed by 36 cycles of $94^{\circ} \mathrm{C}$ for $45 \mathrm{~s}, 58^{\circ} \mathrm{C}$ for $45 \mathrm{~s}$ and $72^{\circ} \mathrm{C}$ for $1 \mathrm{~min} 30 \mathrm{~s}$; and concluding with $3 \mathrm{~min}$ at $72^{\circ} \mathrm{C}$. Amplification was verified by electrophoresis in a $0.9 \%$ agarose gel stained with ethidium bromide and resulting PCR products were purified using a Geneclean ${ }^{\circledR}$ Spin Kit (MP Biomedicals, LLC, Santa Ana, CA, USA). Purified DNA was sequenced in both directions at the Institute for Integrated Genome Biology, UCR. Sequences were aligned and compared by eye in BioEdit v. 7.0.5.3 (Hall, 1999). Resulting sequences were deposited in GenBank (Benson et al., 2014).

Males and females were checked for infection with Wolbachia using a diagnostic PCR that targets the 16s region of the bacterium (Werren \& Windsor, 2000). PCR was performed in $25 \mathrm{~L}$ reactions containing $2 \mathrm{l}$ of DNA template, $1 \times$ ThermoPol PCR Buffer (NEB), 200 M each dNTP, 1 U Taq polymerase (NEB) and $0.8 \mathrm{M}$ each of the primers W-Specf and WSpecr (Werren \&Windsor, 2000). The PCR cycling consisted of one cycle of $94^{\circ} \mathrm{C}$ for $2 \mathrm{~min}$; followed by 40 cycles of $94^{\circ} \mathrm{C}$ for $30 \mathrm{~s}, 55^{\circ} \mathrm{C}$ for $45 \mathrm{~s}$ and $72^{\circ} \mathrm{C}$ for $1 \mathrm{~min} 30 \mathrm{~s}$; and concluding with $10 \mathrm{~min}$ at $72^{\circ} \mathrm{C}$. Amplification was checked by electrophoresis in a $0.9 \%$ agarose gel. Wolbachia infection status of each specimen was assigned based on the presence/absence of a 438 bp diagnostic band (Werren \& Windsor, 2000).

\section{Results and conclusions}

\section{Taxonomy}

\section{Primary parasitoid}

The primary parasitoid, $P$. euphyllurae, had been identified using the keys to the Palaearctic species of the genus Psyllaephagus Ashmead by Trjapitzin (1967, 1982, 1989), the original description (Masi, 1911) and the redescription of the female by Mercet (1921), and then compared with the original syntypes of this species. A male of this species from 
Sfax, Tunisia, reared from $E$. olivina, was mentioned by Ferrière (1961) who, however, did not provide any other details. Therefore, the male of P. euphyllurae is described here for the first time while the female is redescribed and illustrated to facilitate its recognition.

\section{Psyllaephagus euphyllurae (Masi, 1911)}

Figures 1-4.

Encyrtus euphyllurae Masi, 1911: 169-171 (as "Encyrtus euphyllurae Silv.[estri] in litt."). Original type localities: Bevagna, Perugia, Italy and Catania, Sicily, Italy; of the lectotype designated here: Catania.

Psyllaephagus euphyllurae (Masi): Mercet, 1921: 700-702 (as "P. euphyllurae "(Silvestri)": redescription, distribution, illustration of female); Gahan \& Waterston, 1926: 375 (as P. euphyllurae "(Silv.[estri])": host association, distribution); Ferrière, 1961: 46 (distribution, host), 48 (key); Trjapitzin, 1967: 194 (key, distribution, host); Trjapitzin, 1982: 398 (key, distribution, host); Trjapitzin, 1986: 58 (comparison with $P$. hyperboreus Trjapitzin, type information); Trjapitzin, 1989: 262 (key, distribution, host); Evans \& Abd-Rabou, 2013: 125 (list, distribution, hosts).

Type material examined: Lectotype female (Figure 1) (DEZA), here designated to avoid any possible confusion regarding the status of the type specimens of this taxon or its identity, labeled: 1. "Catania Euphyll. 9-VII-909". The lectotype (mounted on the same card together with 12 other original syntype females) is a laterally-mounted specimen on the left at the apex of the card (Figure 1); it is in fair condition, complete. Paralectotypes: the aforementioned 12 females; also 10 females (DEZA) on another card labeled: "Catania Euphyll. 28-VI-909". Some of the paralectotype specimens are incomplete, lacking either the heads or only the antennae.

The species was described from an unspecified number of syntype females. According to Trjapitzin (1986), 2 females of $P$. euphyllurae from Sicily labeled "Encyrtus euphyllurae Silv. Catania" were sent to him (as an exchange) by Gennaro Viggiani from DEZA to ZIN (Zoological Institute, now Russian Academy of Sciences, Saint Petersburg, Russia); these without any doubt also are the original syntypes of this species and thus are designated here as paralectotypes. Mercet (1921) mentioned a female specimen (as forma italiana or forma típica) of $P$. euphyllurae from Italy sent to him by Filippo Silvestri, but without indicating its type status or providing any label details.

Material examined (all emerged in UCR quarantine, except when indicated otherwise, from parasitized nymphs of $E$. olivina on olive, Olea europaea L.): Spain: Catalonia: near La Jana, $40.49635^{\circ} \mathrm{N}$ $00.23692^{\circ} \mathrm{E}, 313 \mathrm{~m}, 13 . \mathrm{v} .2013$, C.H. Pickett (emerged 26.v.2013, S\&R 1353-03), 3 females. Near Les Cases d'Alcanar: $40.56043^{\circ} \mathrm{N} 00.53147^{\circ} \mathrm{E}$, 14 m, C.H. Pickett: 11.v.2013, 1 female (emerged 21.v.2013, S\&R 13-5303); 12.v.2013, 1 female (emerged 26.v.2013, S\&R 13-53-03); 13.v.2013, 3 females (emerged 23.v.2013*, 24.v.2013, and 28.v.2013, S\&R 13-53-

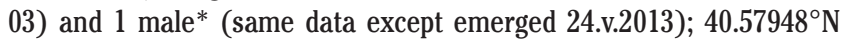
$00.55229^{\circ} \mathrm{E}, 11 \mathrm{~m}, 13 . v .2013$, C.H. Pickett (emerged 31.v.2013, S\&R 1353-03), 1 female; $40.56314^{\circ} \mathrm{N} 00.53565^{\circ} \mathrm{E}, 6 \mathrm{~m}, 8 . v .2013$, C.H. Pickett, K. Hoelmer, 2 females (emerged 25.v.2013 and 26.v.2013, S\&R 13-53-01). Near Sant Carles de la Ràpita: $40.63309^{\circ} \mathrm{N} 00.59722^{\circ} \mathrm{E}, 13 \mathrm{~m}, 8 . \mathrm{v} .2013$, C.H. Pickett, K. Hoelmer, 3 females (emerged 23.v.2013*, 27.v.2013, and 29.v.2013, S\&R 13-53-01) and 1 male (emerged 30.v.2013 in California Department of Food and Agriculture (CDFA) quarantine laboratory, Sacramento, California, USA, coll. C.H. Pickett). Murcia: near Jumilla, $38.39974^{\circ} \mathrm{N} 1.38686^{\circ} \mathrm{W}, 411$ m, 10.v.2013, C.H. Pickett, J. A. Sánchez, 2 females (emerged 26.v.2013, S\&R 13-53-02) and 1 male (same data except emerged v.2013 in CDFA quarantine laboratory, coll. C.H. Pickett). USA, California, Riverside Co., Riverside, UCR quarantine laboratory: 23.vii.2013, J.M.L. Jones, 1 female (first generation progeny from colony on E. olivina on olive), originally from: Spain, Catalonia, near Sant Carles de la Ràpita, $40.63309^{\circ} \mathrm{N} 0.59722^{\circ} \mathrm{E}, 13 \mathrm{~m}, 8 . v .2013$, C.H. Pickett, K. Hoelmer (emerged 25.v.2013 in UCR quarantine, S\&R
13-53-01, coll. by J.M.L. Jones); also 1 female (same data except second generation progeny, collected from colony 13.ix.2013). 16.vi.2013, J.M.L. Jones, 1 female (first generation progeny from colony on $E$. olivina on olive), originally from: Spain, Catalonia, near Les Cases d'Alcanar, $40.56043^{\circ} \mathrm{N} 0.53147^{\circ} \mathrm{E}, 14 \mathrm{~m}, 11 . v .2013$, C.H. Pickett (emerged 21.v.2013 in UCR quarantine, S\&R 13-53-03, coll. by J.M.L. Jones); also 1 female (same data except second generation progeny, collected from colony 12.viii.2013), 2 females (same data except third generation progeny, collected from colony 11.ix.2013 and 18.ix.2012), and 1 female (same data except fourth generation progeny, collected from colony 13.x.2013.

Additional material examined: France, Hérault, near Puéchabon, $43.71127^{\circ} \mathrm{N} 3.62394^{\circ}$ E, 192 m, 14.v.2009, C.H. Pickett, K.M. Daane (from Euphyllura sp. on olive), 2 females. Greece, Central Macedonia, Thessaloniki, Thermaikos, near Epanomi, $40.38841^{\circ} \mathrm{N} 22.96091^{\circ} \mathrm{E}, 20$ m, 10.v.2009, C.H. Pickett, K.M. Daane (from Euphyllura sp. on olive), 1 female. Spain: Catalonia, near Amposta and Sant Carles de la Ràpita, $40.66133^{\circ} \mathrm{N} 0.58362^{\circ} \mathrm{E}, 11 \mathrm{~m}, 5 . v .2009$, C.H. Pickett, K.M. Daane (from Euphyllura sp. on olive), 2 females. Murcia, near Jumilla, $38.39973^{\circ} \mathrm{N}$ $1.38706^{\circ} \mathrm{W}, 410$ m, 4.v.2009, C.M. Pickett, K.M. Daane (from Euphyllura sp. on olive), 2 females.

Redescription (female, specimens from Spain): Body length 1.2-1.8 $\mathrm{mm}$ (critical point-dried specimens). Body (Figure 2B) mostly dark brown except sometimes gaster brown; head with strong bluish-violet metallic tinge, mesoscutum, scutellum, and first gastral tergite with a strong greenish metallic tinge; scape and pedicel dark brown, flagellum brown; coxae dark brown, femora and tibiae light to dark brown, tarsi light brown to brown.

Head, dorsal part of pronotum, mesoscutum, axilla, and scutellum with distinct mesh-like sculpture; sculpture on scutellum more reticulate but with smaller cells than that on mesoscutum. Pronotum, mesoscutum, axilla, and scutellum with short, dusky setae. Propodeum laterally with inconspicuous whitish pubescence.

Head a little wider than high. Ocelli in right triangle. Mandible with 1 tooth and a wide truncation; labial palpus 3-segmented, maxillary palpus 4-segmented.

Antenna (Figure 2A) inserted at lower eye margin level. Radicle about $0.2 x$ total scape length, rest of scape slender, about $3.7 x$ as long as wide, a little wider closer to apex, with reticulate sculpture. Pedicel about 1.6x as long as wide, longer than any funicle segment. Funicle segments about as long as wide, F6 the widest; F1 without mps or with

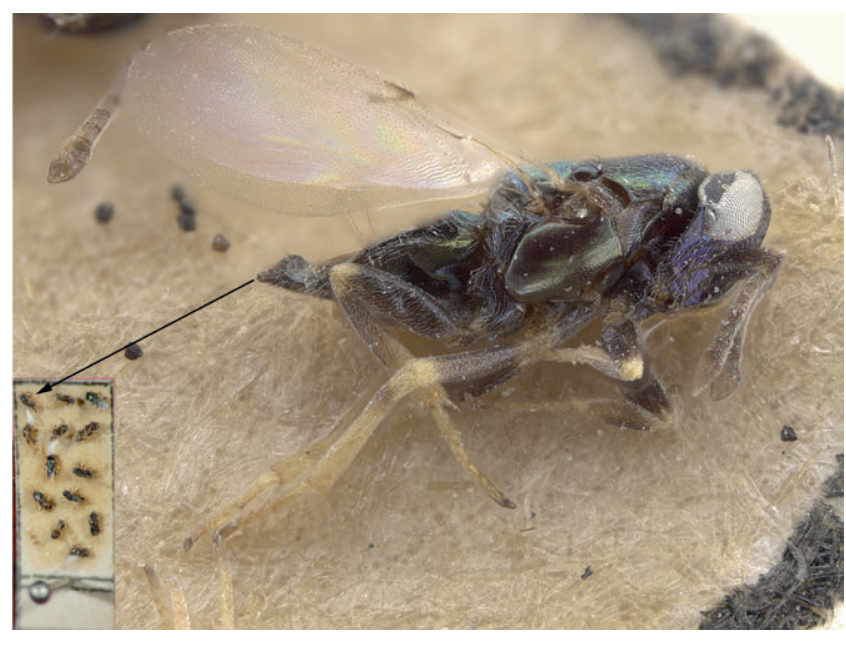

Figure 1. Psyllaephagus euphyllurae, female (lectotype of Encyrtus euphyllurae): habitus (an arrow points to its position on the card). 
$1 \mathrm{mps}$, F2-F6 each with several short mps. Clava 3-segmented, 2.1-2.2x as long as wide and as long as combined length of 3 preceding funicle segments (F4-F6); each claval segment with many mps.

Mesosoma shorter than metasoma. Pronotum very narrow. Mesoscutum about $1.5 \mathrm{x}$ as wide as long. Scutellum slightly wider than long, almost as long as mesoscutum; scutellar placoid sensilla a little closer to posterior margin of scutellum than to its anterior margin and close to each other.

Wings not abbreviated, fore wing extending far beyond apex of gaster. Fore wing (Figure 2C) 2.2-2.3x as long as wide; disc hyaline throughout, without an infuscation at base of stigmal vein; postmarginal vein about $0.6 \mathrm{x}$ length of stigmal vein; marginal setae very short, longest at most $0.03 \mathrm{x}$ maximum wing width. Hind wing about $3.6 \mathrm{x}$ as long as wide, with disc hyaline; longest marginal seta $0.12-0.13 \mathrm{x}$ maximum wing width.

Mesotibial spur about $0.6 \mathrm{x}$ length of mesobasitarsus.

Ovipositor occupying $0.6-0.7 x$ length of gaster, exserted slightly beyond gastral apex; ovipositor length:metatibia length ratio about 0.6:1.

Measurements of the type specimens (all air-dried): Body length of the lectotype $1.189 \mathrm{~mm}$, of the paralectotypes $1.123-1.486 \mathrm{~mm}$.

Description (male, specimens from Spain): Body length about 1.1 $\mathrm{mm}$ (one air-dried specimen with a collapsed head). Body dark brown to black (head and mesosoma with faint greenish metallic tinge), antenna brown, legs brown to dark brown. Head (Figure 3A) with vertex in frontal view about $0.5 \mathrm{x}$ head width. Antenna (Figure $3 \mathrm{~B}$ ) with scape minus short radicle about $1.9 \mathrm{x}$ as long as wide; pedicel much shorter than any flagellar segment; flagellum with very short setae; all funicle segments longer than wide and more or less subequal in length (F6 slightly shorter), F2 and F3 the widest, each funicle segment with several short mps (all of them apical); clava entire, about 2.7x as long as wide, a little narrower than F1-F4, as wide as F5, and slightly wider than F6, with several short mps (all of them in the middle and at apex). Mesosoma a little longer than metasoma (Figure 3C). Fore wing (Figure 4A) about 2.2x as long as wide, with disc hyaline; marginal setae very short as in female. Hind wing (Figure 4A) hyaline, about $3.3 \mathrm{x}$ as long as wide; marginal setae short. Mesotibial spur a little more than $0.8 \mathrm{x}$ length of mesobasitarsus. Genitalia (Figure 4B) elongate, occupying about $0.6 \mathrm{x}$ length of gaster; digitus with 2 short spines.

Distribution: Egypt (Japoshvili \& Noyes, 2005b), France (Panis, 1998; Aversenq et al., 2005); Greece (Stavraki, 1980), Italy (Masi, 1911), Portugal (Mercet, 1921), Spain (Trjapitzin, 1967, 1982, 1989), Tunisia (Anonymous, 1957; Ferrière, 1961; Arambourg, 1964), Turkey (Trjapitzin, 1989; Dirlik \& Öncüer, 1990; Öncüer, 1991; Trjapitzin \& Doğanlar, 1997; Japoshvili \& Noyes, 2005a). The previous distribution records of this species from Spain by Trjapitzin (1967, 1982, 1989), however, did not mention any specimens examined.

Hosts: Euphyllura olivina (Costa) (Masi, 1911 [as "Euphyllura oleae"]; Mercet, 1921; Anonymous, 1957; Ferrière, 1961; Arambourg, 1964; Chermiti et al., 1987 [as "P. euphyllurae Silv."]), E. phillyreae Foerster (Dirlik \& Öncüer, 1990; Öncüer, 1991; Trjapitzin \& Do anlar, 1997), and $E$. straminea Loginova (Japoshvili \& Noyes, 2005b) (Hemiptera, Liviidae).

According to Dr. André Panis (Panis, personal communication, 2014), in Provence, France $P$. euphyllurae parasitizes $E$. phillyreae on Phillyrea angustifolia L., and in Béja and Sousse Governorates of
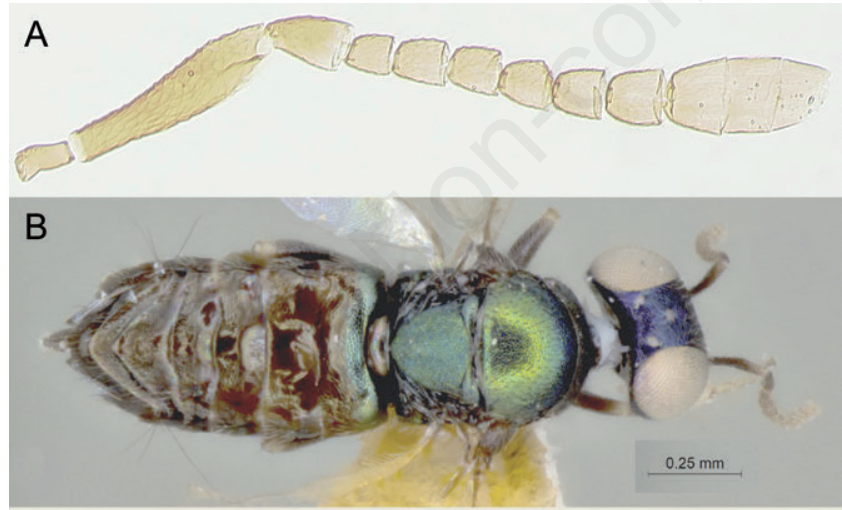

C

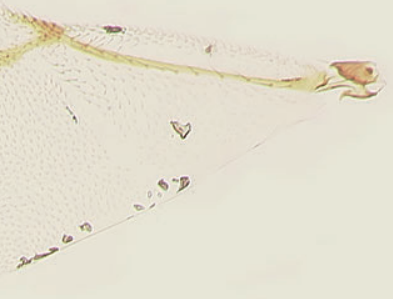

Figure 2. Psyllaephagus euphyllurae, female (Catalonia, Spain): A) antenna; B) body; C) fore wing.

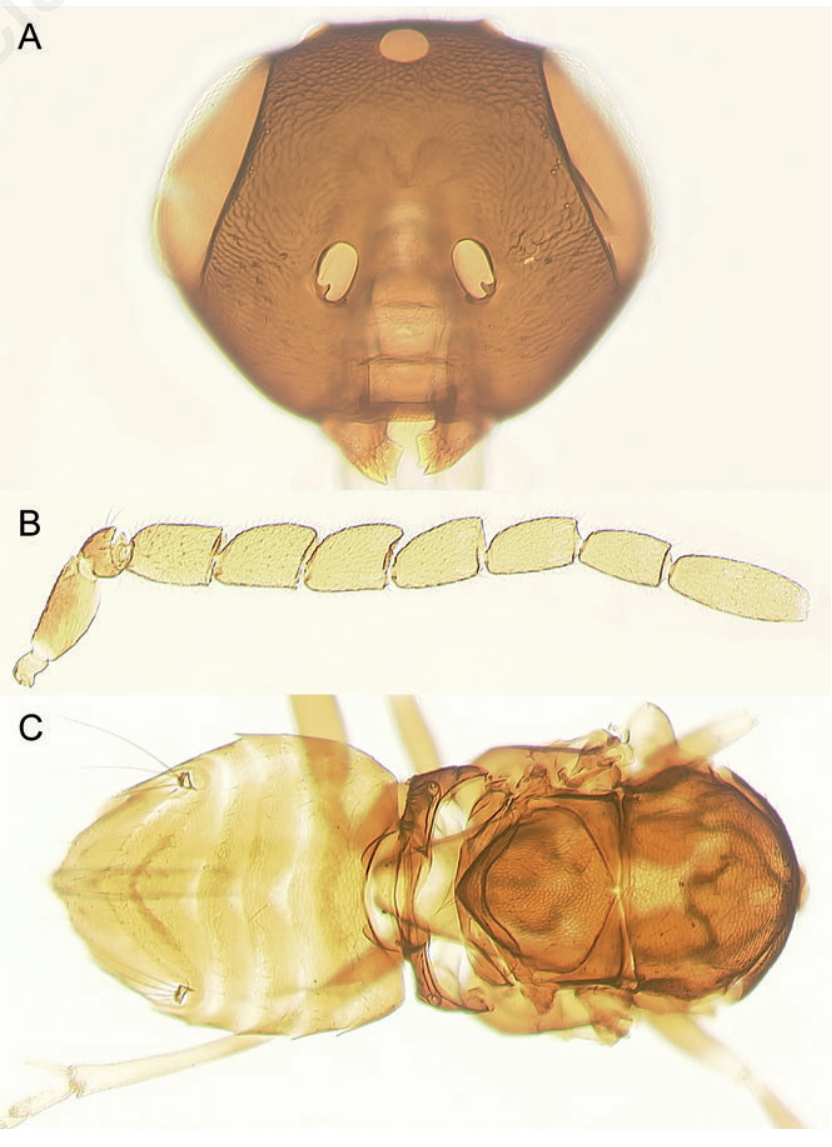

Figure 3. Psyllaephagus euphyllurae, male (Catalonia, Spain): A) head (frontal view); B) antenna; C) mesosoma and metasoma. 
Tunisia it attacks both $E$. olivina and $E$. phillyreae on olive trees.

Biology: Some bio-ecological aspects and developmental characteristics of $P$. euphyllurae parasitizing $E$. olivina were investigated by Chermiti (1983) and Chermiti et al. (1987) who unfortunately did not mention where the studies were conducted - in Tunisia according to Dr. André Panis (Panis, personal communication, 2014).

\section{Hyperparasitoids}

Two species of hyperparasitoids have also emerged from the parasitized olive psylla nymphs collected in Catalonia (but none from Murcia): numerous specimens of $A$. trapezoidea and one specimen of Pachyneuron sp. (Hymenoptera, Pteromalidae, Pteromalinae). Among the 221 wasps that emerged from the samples from Catalonia, 86 (ca. $39 \%$ ) were $A$. trapezoidea and 134 (ca. 61\%) were the primary parasitoid P. euphyllurae. Even though we, unfortunately, had no capacity to conduct experimental work in quarantine to prove that $A$. trapezoidea attacks $P$. euphyllurae in parasitized nymphs of $E$. olivina, there is no doubt whatsoever that this is indeed the case because this encyrtid was the only primary parasitoid of the olive psylla found in Spain, and species of the charipine genus Apocharips Fergusson are known to be hyperparasitoids of psyllids through the Encyrtidae (Ferrer-Suay et al., 2013).

\section{Apocharips trapezoidea (Hartig, 1841)}

\section{Figures 5-6.}

Material examined (all emerged in UCR quarantine from parasitized nymphs of $E$. olivina on olive): Spain, Catalonia: near Les Cases d'Alcanar: $40.56043^{\circ} \mathrm{N} 00.53147^{\circ} \mathrm{E}, 14 \mathrm{~m}, 13 . v .2013$, C.H. Pickett (emerged 30.v.2013, S\&R 13-53-03), 1 female (USNM) and 1 male (USNM) (same data except collected 12.v.2013); $40.57948^{\circ} \mathrm{N}$ $00.55229^{\circ} \mathrm{E}, 11 \mathrm{~m}, 13 . v .2013$, C.H. Pickett (emerged 23.v.2013, S\&R 1353-03), 1 female and 1 male (same data except emerged 29.v.2013); $40.56314^{\circ} \mathrm{N} 00.53565^{\circ} \mathrm{E}, 6 \mathrm{~m}, 8 . v .2013$, C.H. Pickett, K. Hoelmer (emerged 28.v.2013, S\&R 13-53-01), 1 male. Near Sant Carles de la Ràpita: $40.63309^{\circ} \mathrm{N} 00.59722^{\circ} \mathrm{E}, 13 \mathrm{~m}, 8 . v .2013$, C.H. Pickett, K. Hoelmer (emerged 23.v.2013, S\&R 13-53-01), 1 female and 1 male (same data except emerged 24.v.2013); near Sant Carles de la Ràpita, $40.59252^{\circ} \mathrm{N} 00.55462^{\circ} \mathrm{E}, 49 \mathrm{~m}$, 8.v.2013, C.H. Pickett, K. Hoelmer (emerged 31.v.2013, S\&R 13-53-01), 1 female.

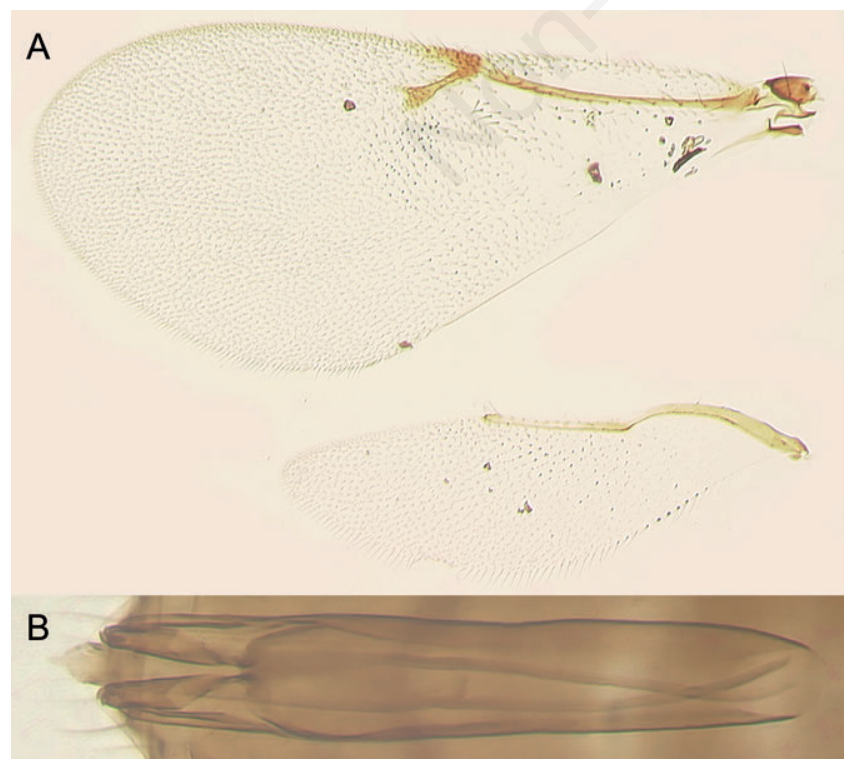

Figure 4. Psyllaephagus euphyllurae, male (Catalonia, Spain): A) a pair of wings; B) genitalia.
Additional material examined: France, Hérault, near Puéchabon, $43.71127^{\circ} \mathrm{N} 3.62394^{\circ} \mathrm{E}, 192 \mathrm{~m}, 14 . v .2009$, C.H. Pickett, K.M. Daane (from Euphyllura sp. on olive), 3 females and 1 male.

Comments: A female (Figure 5A) and a male (Figure 6A) of $A$. trapezoidea are illustrated to facilitate their recognition; the female antenna (Figure 5B) has 11 flagellomeres whereas the male antenna (Figure 6B) has 12 flagellomeres.

Previously, Silvestri (1915) described (in a footnote, p. 274) A. eleaphila (Silvestri) [as "Alloxista eleaphila Silv."] from Italy as a parasitoid of

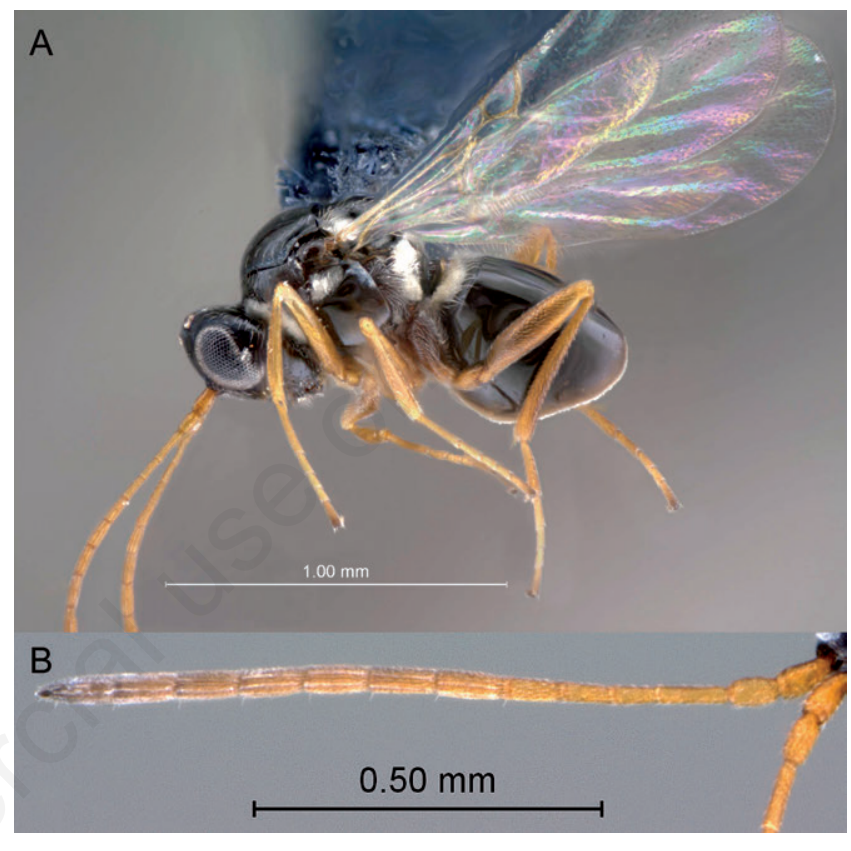

Figure 5. Apocharips trapezoidea, female (Catalonia, Spain): A) habitus; B) antenna.

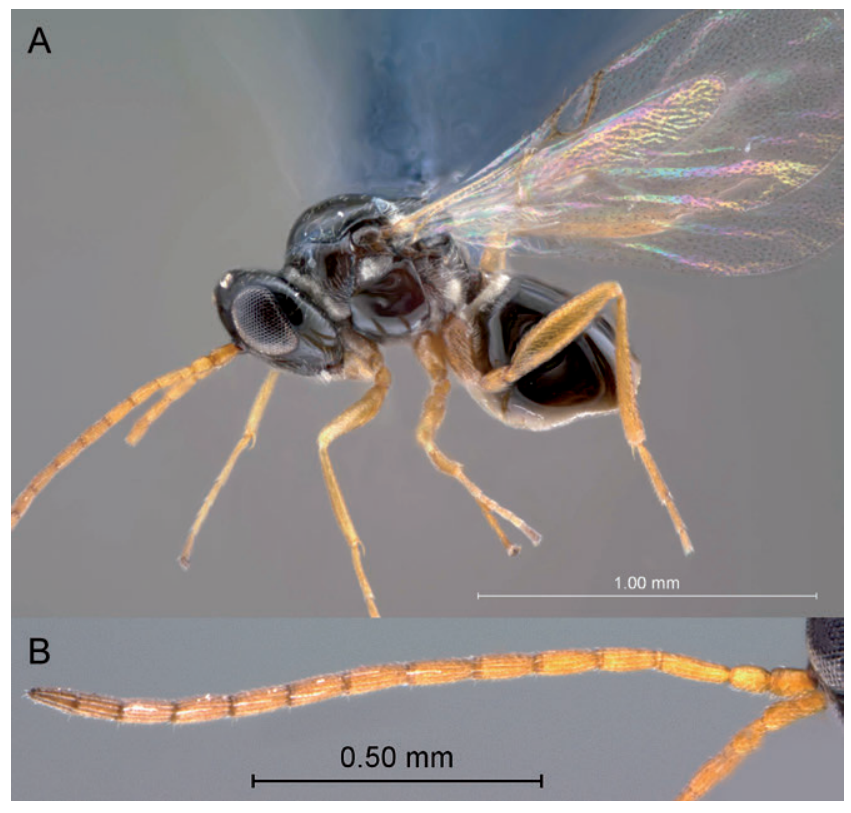

Figure 6. Apocharips trapezoidea, male (Catalonia, Spain): A) habitus; B) antenna. 
E. olivina; this charipine species was recently synonymized under $A$. trapezoidea by Ferrer-Suay et al. (2013) who also designated a lectotype of Silvestri's species from specimens collected in Vittoria, Sicily. Based on the condition of the lectotypes of both A. eleaphila and A. peraperta (Silvestri) (the latter was described from Eritrea simultaneously with $A$. eleaphila), the fourth author here questions the synonymy of these species with A. trapezoidea. Both lectotypes (received on loan from DEZA with Prof. Gennaro Viggiani's kind help) are slide-mounted, crudely dissected, and in relatively poor curatorial condition overall. Despite these facts, Ferrer-Suay et al. (2013) provide evidence for their synonymy [based on the shape of the radial cell, proportional (length) of the flagellomeres, and the shape of the propodeal carinae] but ignore the rampant morphological plasticity inherent in hyperparasitoid morphology, especially within Charipinae. This phenomenon is readily apparent in the Silvestri types, where the relative lengths of flagellomeres are clearly different between two specimens on the same slide, and the marginal cell veins run from parallel to convergent. An additional complication can be found with the propodeal carinae, in that among the type specimens, they are only visible on a single specimen. The host data is another problem here: the only host data for A. trapezoidea prior to the synonymization of the two Silvestri species was that of a "Psylla sp." (Fergusson, 1986); since very little is known regarding host specificity within Apocharips, it's currently impossible to determine whether the host records reported here for $A$. trapezoidea do indeed reflect a broad host range for the species, or, in fact, the $A$. trapezoidea reported here are actually $A$. eleaphila synonymized by Ferrer-Suay et al. (2013). While we take no nomenclatural action at the present time, we do suggest additional collecting from the type localities of the Silvestri species, confirming host species identifications, and generating contemporary collections for more advanced morphological and molecular diagnostics research. In the end, it is quite possible that $A$. trapezoidea, here recorded from Spain, may turn out to be conspecific with the specimens reared by F. Silvestri from the same psyllid host in Sicily.

\section{Pachyneuron sp.}

Material examined: Spain, Catalonia, near Les Cases d'Alcanar, $40.57948^{\circ} \mathrm{N} 0.55229^{\circ} \mathrm{E}, 11 \mathrm{~m}, 13 . v .2013$, C.H. Pickett (emerged 29.v.2013 in UCR quarantine from a parasitized nymph of $E$. olivina on olive, S\&R 13-53-03), 1 female.

\section{Molecular matching of the sexes of Psyllaephagus euphyllurae and presence of bacterial Wolbachia symbiont}

The ITS2 of two females and one male of $P$. euphyllurae were identical (GenBank accession numbers KJ747349, KJ747350 and KJ747351) thus providing a proof of their conspecificity.

In our diagnostic PCR, ten of the eleven P. euphyllurae females (both from the field in Spain and from the colony at UCR) tested were infected with Wolbachia, revealed by the amplification of a PCR product of approximately $438 \mathrm{bp}$. Of the two males tested, one was infected (producing a faint diagnostic PCR product) but the other was uninfected. Under laboratory conditions, the parasitoid reproduces exclusively by thelytoky; the role of the few occasional males that have been found in the field in Spain is not fully understood.

The single female specimen of Pachyneuron sp. was also infected with Wolbachia.

\section{References}

ANONYMOUS, 1957 - Liste d'identification No 2 (Présentée par le secrétatiat du Service d'identification des Entomophages). Entomophaga 2: 313-332.

ARAMBOURG Y., 1964 - Characteristics of the insect population of the olive tree in the Sahel at Sfax. - Ann. Inst. Nat. Rech. Agron. Tunisie 37: 1-137.

AVERSENQ S., GRATRAUD C., PINATEL C., 2005 - Ravageurs et auxiliaires des oliviers. Synthèse de trois ans d'observations dans le SudEst de la France. - Phytoma 586: 32-36.

BENSON D.A., CAVANAUGH M., CLARK K., KARSCH-MIZRACHI I., LIPMAN D.J., OSTELL J., SAYERS E.W.M., 2014 - GenBank. - Nucl. Acids Res. 42: D32-D37.

CHERMITI B., 1983 - Contribution à l'étude bio-écologique du psylle de l'olivier, Euphyllura olivina Costa (Homoptera: Psyllidae) et de son endoparasite, Psyllaephagus euphyllurae Silv. (Hymenoptera: Encyrtidae). - Thèse Docteur Ingénieur, Université d'Aix-Marseille.

CHERMITI B., HAWLITZKY N., BOULAY C., ONILLON J.C., 1987 Quelques caractéristiques du développement de l'endoparasite Psyllaephagus euphyllurae [Hymenoptere (sic), Encyrtidae] et exploitation de son hôte Euphyllura olivina [Homoptere (sic), Psyllidae]. - Entomophaga 31: 351-361.

DIRLIK S., ÖNCÜER C., 1990 - Investigations of the species of the family Encyrtidae (Hymenoptera) in Turkey, their distribution hosts and activity. - Ege Üniv. Fen Bil. Enst. Derg. 1: 79-85.

EVANS G.A., ABD-RABOU S., 2013 - An annotated list of the encyrtids of Egypt (Hymenoptera: Chalcidoidea: Encyrtidae). - Acta Phytopath. Entomol. Hung. 48: 107-128.

FERGUSSON N.D.M., 1986 - Charipidae, Ibaliidae \& Figitidae: Hymenoptera: Cynipoidea. Handbooks Ident. British Ins. 8: 1-55.

FERRER-SUAY M., PARETAS-MARTÍNEZ J., PUJADE-VILLAR J., 2013 Revision of Apocharips Fergusson (Hymenoptera: Figitidae: Charipinae) with description of three new species from Colombia. - Zootaxa 3646: 487-500.

FERRIÈRE C., 1961 - Encyrtides palearctiques parasites de psylles. Entomophaga 6: 39-51.

GAHAN A.B., WATERSTON J., 1926 - Notes on Encyrtidae (Hym.Chalcidoidea) bred from psyllids, with description of a new species. - Bull. Entomol. Res. 16: 373-375.

GIBSON G.A.P., 1997 - Chapter 2. Morphology and terminology. In: GIBSON G.A.P., HUBER J.T., WOOLLEY J.B., Annotated keys to the genera of Nearctic Chalcidoidea (Hymenoptera). - NRC Research Press, Ottawa: 16-44.

HALL T.A., 1999 - BioEdit: a user-friendly biological sequence alignment editor and analysis program for Windows 95/98/NT. - Nucl. Acids Symp. Ser. 41: 95-98.

JAPOSHVILI G., NOYES J.S., 2005a - Checklist and new data on Encyrtidae of Transcaucasia and Turkey (Hymenoptera: Chalcidoidea). - Zoosyst. Ross. 14: 135-145.

JAPOSHVILI G.0., NOYES J.S., 2005b - New record of Encyrtidae (Hymenoptera: Chalcidoidea). - Caucasian Entomol. Bull. 1: 159-160.

JARDAK T., SMIRI H., MOALLA M., KHALFALLAH H., 1985 - Tests to assess the damage caused by the olive psyllid Euphyllura olivina Costa (Homoptera, Psyllidae): preliminary data on the harmfulness threshold. In: CAVALLORO R., CROVETTI A., Integrated pest control in olive-groves. - Proceedings of the CEC/FAO/IOBC International Joint Meeting, Pisa, 3-6 April 1984, Commission of the European Communities, A.A. Balkema, Rotterdam-Boston: 270-284.

MASI L., 1911 - Contribuzioni alla conoscenza dei Calcididi italiani. (Parte IV). - Boll. Lab. Zool. Gen. Agr. R. Scuola Super. Agric. Portici 5: 140-171.

MERCET R.G., 1921 - Fauna Ibérica. Himenópteros Fam. encírtidos. Museo Nacional de Ciencias Naturales, Madrid: I-XI + 732 pp.

ÖNCÜER C., 1991 - A catalogue of the parasites and predators of insect pests of Turkey. - Ege Üniv. Zir. Fak. Yay. 503: i-vi + 354 pp.

PANIS A., 1998 - Evaluation d'hyménoptères en tant qu'indicateurs de la qualité biologique d'un milieu agricole. - Cahiers AIDEC (Cahiers de l'Association Internationale des Entretiens Écologiques) 36: 55-73. 
PORTER C.H., COLLINS F.H., 1991 - Species-diagnostic differences in a ribosomal DNA internal transcribed spacer from the sibling species Anopheles freeborni and Anopheles hermsi (Diptera: Culicidae). Am. J. Trop. Med. Hyg. 45: 271-279.

SILVESTRI F., 1915 - Contributo alla conoscenza degli insetti dell' olivo dell' Eritrea e dell'Africa meridionale. - Boll. Lab. Zool. Gen. Agr. R. Scuola Super. Agric. Portici 9: 240-334.

STAVRAKI H.G., 1980 - Biology of Euphyllura sp. (Homoptera: Psyllidae) in an olive grove in Attiki (Greece). - Med. Fac. Landbouwwetenschappen, Rijksuniv. Gent 45: 603-611.

TRJAPITZIN V.A., 1967 - [Encyrtids (Hymenoptera, Encyrtidae) of the Maritime Territory]. - Trudy Zoologicheskogo Instituta, Akademiya Nauk SSSR [Proc. Zool. Inst., Leningrad] 41: 173-221. [In Russian].

TRJAPITZIN V.A., 1982 - Key to Palaearctic species of the genus Psyllaephagus [Hym.: Encyrtidae]. - Entomophaga 26: 395-399.

TRJAPITZIN V.A., 1986 - [New Palaearctic species of the genus Psyllaephagus Ashmead (Hymenoptera, Encyrtidae)]. - Trudy
Zoologicheskogo Instituta, Akademiya Nauk SSSR [Proc. Zool. Inst., Leningrad] 159: 57-63. [In Russian].

TRJAPITZIN V.A., 1989. - [Parasitic Hymenoptera of the fam. Encyrtidae of Palaearctics]. - Nauka, Leningrad division, Leningrad. [In Russian].

TRJAPITZIN V.A., DOĞANLAR M., 1997 - [A review of encyrtids (Hymenoptera, Encyrtidae) of Turkey]. - Entomol. Obozr. 76: 213222. [In Russian].

TZANAKAKIS M.E., 2006 - Insects and mites feeding on olive: distribution, importance, habits, seasonal development and dormancy. Koninklijke Brill NV, Leiden, The Netherlands.

WERREN J.H., WINDSOR D.M., 2000 - Wolbachia infection frequencies in insects: evidence of a global equilibrium? - Proc. R. Soc. London Ser. B 267: 1277-1285.

WHITE T.J., BURNS T., LEE S., TAYLOR T.J., 1990 - Amplification and direct sequencing of fungal ribosomal RNA genes for phylogenetics. In: INNIS M.A., GELFAND D.H., SNINSKY J.J., WHITE T.J., PCR protocols: a guide to methods and applications. - Academic Press, Burlington: 315-322. 